\title{
BORN OF TWO KOREAS, OF HUMAN BLOOD Monstrosity and the Discourse of Humanity and Pacifism in the Film Bulgasari
}

\author{
Jungman Park \\ Hankuk University of Foreign Studies \\ jungmany@gmail.com
}

\begin{abstract}
As in the Western world, Korea has a variety of mythical monsters. Among them is Bulgasari, an iron-eating monster, which will be the main topic of this paper. The monster's name "Bulgasari" has a paradoxical meaning in Korean, which is "cannot be killed but can be killed by fire." The meaning of the name represents the wide gamut of ambivalent identity ranging from physical to metaphorical aspects of the monster. It also provides a uniquely Korean reception and interpretation of being monstrous as distinctive from the archetypal imagery and general understanding of monstrosity as "enduring evil," as seen in most myths and tradition. For instance, Bulgasari's destructive power is frequently portrayed in the myth as a heroic trait to protect social justice by condemning and punishing the evils of society. Such an ambivalent identity as both monster and hero shows that Bulgasari's embodiment of monstrosity is recognized through a different or rather complex mechanism in Korean-specific context, not uniformly recognized as enduring evil. This study traces historical descriptions of the monster Bulgasari in legend, literature, and film adaptation. Especially focusing on the North Korean film Bulgasari (1985), this study explores the way in which the ambivalent identity of the monster develops into discourses of humanity and pacifism, in both Korean-specific and transnational contexts, while mirroring the Korean and global sense of reality situated in this era of SouthNorth division and nuclear holocaust.
\end{abstract}

\section{Keywords}

ambivalence; Bulgasari; humanity; Korean legend; monstrosity; North-Korean film; pacifism 


\begin{abstract}
About the Author
Jungman Park (Ph.D. in Theatre History, University of Illinois, Urbana-Champaign), is Associate Professor in the School of English for Interpretation and Translation at Hankuk University of Foreign Studies, South Korea. His research interests include theatre history and criticism (both Western and Korean), modern British and American drama, cultural studies on American national identity, text-context interplays in theatre and drama, and historico-cultural reading of texts. His publications have appeared in Asian Theatre Journal, Korean Theatre Studies, Journal of Modern British and American Drama, Journal of American Studies, Journal of British and American Studies, Journal of English Language and Language, and Shakespeare Reviews.
\end{abstract}

Kritika Kultura 33/34 (2019/2020): 137-155

(c) Ateneo de Manila University

<http://journals.ateneo.edu/ojs/kk/> 
We have to address this issue of dualism, of emotive ambivalence, in which the monster stands for both the victim and the victimizer. What other forces does the monster embody in the human consciousness aside from pure aggression? Why do we need all these monsters to express these emotions? (Gilmore 5)

\section{INTRODUCTION}

In mythology, monsters are frequently portrayed as hybrid creatures whose bodies are the bizarre combinations of characteristic elements of different animals. In Greek mythology, for example, Chimera is a zoomorphic figure with a lion's head, a goat's body, and a snake's tail. The three-headed Chimera is not just grotesque in shape but also a dreadful monster who spits a deadly firestorm, as described in Homer's epic poem The Iliad (book vi, 212-215) and in Hesiod's Theogony (319321). The Sphinx, appearing in ancient Egyptian mythology, is a winged monster with a woman's head on the body of a lion. Cerberus, a Greek mythological hound known for guarding the entrance of the underworld or Hades, is a three-headed dog with a snake's tail and shaggy mane running down its back (Linebaugh and Rediker 2; Bloomfield 2-3). ${ }^{2}$ Such imagination on and faith in the shape of mythical monsters is not the sole monopoly of the West. Similarly, some monsters in Korean myths and legends are depicted as crossbred animals. Among them is Bulgasari, a mythical and imaginary monster appearing in the Korean folk legends. Seen in the drawings of Kim Du-Ryang, a painter of the mid-Chosun period, Bulgasari has the shape of a hybrid animal with a bear's body, elephant's nose, rhinoceros's eyes, tiger's feet and bull's tail (Figure 1). ${ }^{3}$ It has hacksaw-like teeth and its entire body is covered with needle-shaped hairs (Yoon, Minhwa Iyagi 147), and it radiates a fearsome aura comparable to the lethal fire-breathing Chimera.

Throughout history, mythological monsters have been generally regarded as a "symbol of disorder and resistance" or "powerful threat to the building of state" (Linebaugh and Rediker 2). This formula is justified in the Hercules-Hydra myth. Hydra, a venomous and evil monster, has nine heads and razor-sharp teeth in the mouth of each head. But such external appearance alone does not explain the monstrosity of the Hydra. This monster also has a special ability which completes its monstrosity, which is the ability to grow back and restore its heads whenever they are lopped off by Hercules, consequently escaping every crisis of potential death and extending its own monstrosity for another day (Gilmore 39-40). The Hydra of the "ever-growing" and "ever-present" heads symbolizes the human recognition of enduring evil. Such monstrosity of the Hydra also reveals the human fears of the enduring nature of evil. In this regard, the Hercules-Hydra myth can be appropriated as a hegemonic text of "monster-making" in which

Kritika Kultura 33/34 (2019/2020): 138-155

(C) Ateneo de Manila University

<http://journals.ateneo.edu/ojs/kk/> 


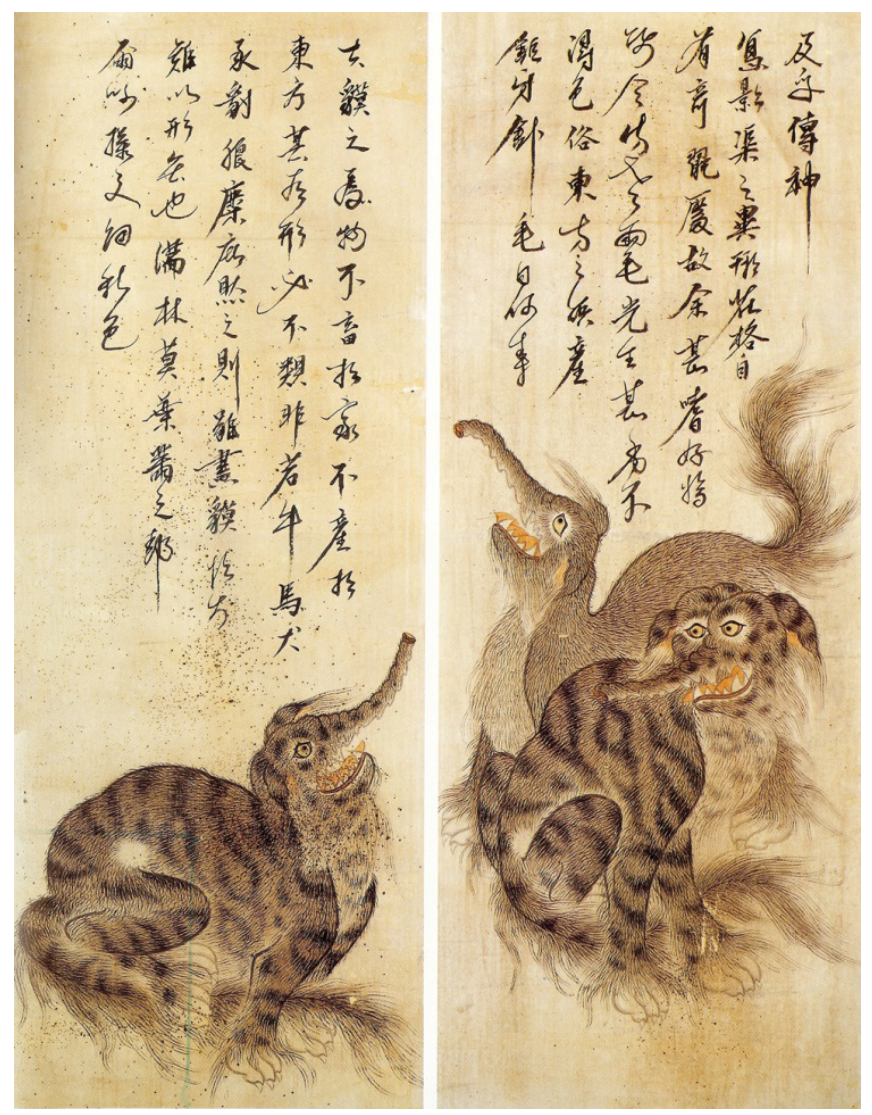

Figure 1. Kim Du-Ryang's drawing of Bulgasari on Folding Screen.

riots, insurrections, mutinies and other forms of antisocial action are defined as monstrosity by the ruling powers and, on the contrary, collective violence to quell such "monstrous" actions is justified as a rational and "humanistic" effort to maintain social normalization and the status quo.

Related to this, the Korean mythological monster Bulgasari provides a unique case of monstrosity, both ontological and epistemological: the process in which its physical shape first begins to form, grows, and is finally completed; and the ways in which its monstrosity is recognized and approached. In addition, Bulgasari's destructive power is frequently portrayed in the myth as a heroic trait and an effort to protect social justice by condemning and punishing the evils of society. Such an ambivalent identity as both monster and hero, explaining only a part of the features that compose the monster, shows that Bulgasari's embodiment of monstrosity is recognized through a different or rather complex mechanism in Korean-specific context, not uniformly recognized as enduring evil. This paper examines the 
meaning of monstrosity embodied by the Korean monster Bulgasari by tracing historical descriptions of the monster in legend, literature, and film adaptation. Especially focusing on the North Korean film Bulgasari (1985), this paper explores the way in which the ambivalent identity of the monster develops into discourses of humanity and pacifism, in both Korean-specific and transnational contexts, while mirroring the Korean and global sense of reality situated in this era of South-North division and nuclear holocaust.

\section{BULGASARI IN LEGEND: AMBIVALENCE OF MONSTROSITY}

The legend of Bulgasari appeared for the first time in the end of the Goryeo Dynasty (913-1392). Thereafter, various subtypes and similar folktales were circulated and handed down by word of mouth. Despite the variety and some difference in content, these stories have one thing in common to say: that the monster Bulgasari began to haunt the Korean peninsula from the late Goryeo Dynasty to the early years of the Chosun Dynasty (1392-1910). The temporal background of Bulgasari's advent is significant. It was a period of political transition, replacement of regime, and power shift. Thus, the scenario that the monster emerged from the uneasy territory of such a turbulent time, as seen in the stories, implies "a discourse about the confusion in social situations" (Cho 168). At the same time, the Bulgasari legend conveys additional stories and sentiment that contemporary grassroots must have had, symbolized by being faced with the confusion caused by the emergence of the monster. Here, a series of questions arise. What did the first face-to-face encounter with this monster mean to the grassroots who had to survive wars and privation in a continuing day-to-day anxiety and fear? Was the encounter a light of salvation or a shade of doom? What message did the dreadful-looking monster herald to these poor people, hope or despair? Was their reception and recognition of the monster as a blessing or as a curse?

According to the legend, the imaginary monster Bulgasari has the ability to defeat nightmares and evil spirits, protect sleeping individuals from incubi, and prevent hurricanes and other natural disasters and the outbreak of plagues such as measles (Chung). Because of this supernatural ability, the image of Bulgasari was sculpted in the form of carved relief on the outer walls of palaces and private houses, chimneys, railings, and pillars, and served as a sentry to watch the evil spirits.

A typical example is the iconographies of Bulgasari carved in the four brick chimneys standing in the rear garden of Gyotaejeon, the queen's quarters, at Gyeongbokgung, the king's palace of the Chosun Dynasty, located in central Seoul.

Kritika Kultura 33/34 (2019/2020): 140-155

(c) Ateneo de Manila University

<http://journals.ateneo.edu/ojs/kk/> 


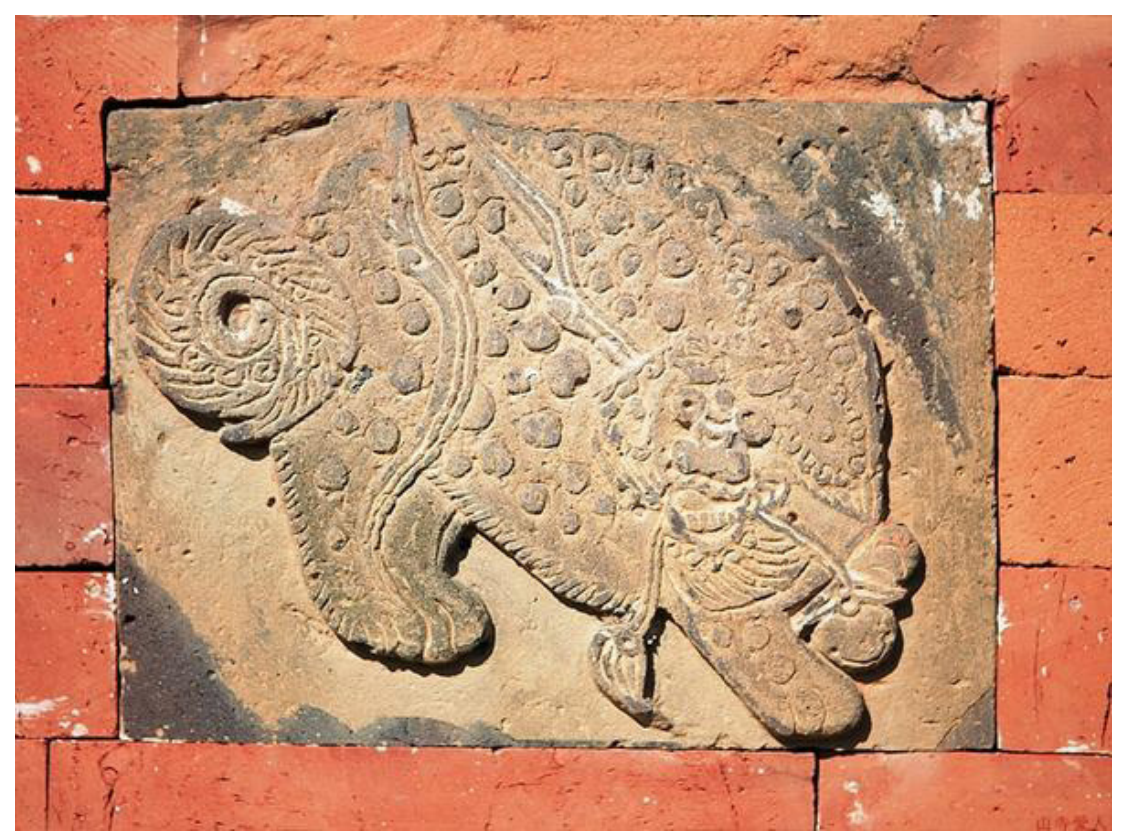

Figure 2. Bulgasari carved in the four brick chimneys of Gyotaejeon

Each side of the four hexagonal chimneys is decorated with auspicious patterns to pray for good luck and health. They include ten symbols of longevity such as the sun, rocks, turtles, and herbs of eternal youth; four gracious plants symbolizing loyalty such as the plum, orchid, chrysanthemum and bamboo; grapes symbolizing the flourishing of posterity; bats symbolizing wealth. The decorative patterns also include reliefs of imaginary and mythical animals such as the dragon-crane hybridborn Bonghwang (equivalent to the Phoenix) and the fire-eating dog Haetae (Heo 183-87). Among them is Bulgasari, and patterns of this imaginary animal are found at the bottom part of the chimneys (Figure 2). Korean traditional architecture had underfloor heating system called gudeul which circulates hot air directly from the fireplace to the underside of thick masonry below the floor of rooms. Connected to the gudeul on the other side, the chimney serves as the smoke exhaust outlet and, at the same time, becomes a passage through which outside air flows directly into the rooms and indoor space. Korean ancestors believed that evil spirits come into the room through the chimney. Accordingly, the images of Bulgasari on the chimneys of Gyotaejeon functioned as an amulet to ward off evil spirits breaking into the queen's chamber (Chung; Yoon, Shinhwa Sok Sangsangdongmul Yeoljeon 163).

The positive reception of Bulgasari was also materialized in literary space. In 1921, during the Japanese occupation of Korea, for instance, a novel entitled Songdo 
Mal Nyeon Bulgasari-jeon (A Tale of Bulgasari at the Last Years of Songdo), written by Hyun Young-Sun, was published. Songdo, the capital of the Goryeo Dynasty, refers to the city of Gaeseong in North Korea today. Set in the declining years of the Goryeo Dynasty, this work depicts Bulgasari as a "righteous animal" that defeats the Red Turban bandits of China devastating the Korean peninsula (Cho 170). ${ }^{4}$ In the novel, the author brings out positive aspects of the monster by making it a patriotic hero saving the country and its people from foreign invasion and threats. Given that this novel was published during the Japanese rule of the Korean peninsula, such a positive image of Bulgasari delivers an additional context: the "colonized" Korean people's longing to break free from Japanese Imperialism. In this respect, the beast's positive image as a patriot can be extended into a manifestation of contemporary Korean society's hopes and aspirations for independence (Cho 172-72).

Negative descriptions of Bulgasari are also found in literary works. A good example is a folktale recorded in the mid-19th century collection of stories Songnam Japji, written by Cho Jae-Sam. It tells the tale of a widow in Songdo at the end of the Goryeo Dynasty. The widow, having lost her husband yet remaining faithful to the deceased beloved, is making her living by sewing. One day, she finds a beetle crawling on her body. Feeling pity for the beetle, the widow gives it something to eat, such as grass, grain and even pieces of fish. But the beetle does not eat at all. However, all of a sudden the beetle swallows a needle the widow has accidently dropped on the floor. The beetle henceforth eats all the metal things in the house and its body expands. Finally, it leaves the house and goes to the city of Songdo, eating all the metal things it can find and sating its appetite. By this time, the beetle has grown into a hideous monster with a bear-sized body, a tiger's face, and a lion's tail. The national army is mobilized to capture the monster, but the army is of no use at all. Swords and spears whet the appetite of the monster, and the armed forces and soldiers are helpless in front of it. The monster, after filling its stomach, even develops an incredible ability to breathe fire. The city of Songdo is eventually on the verge of being burned to ashes.

The destructive power of Bulgasari in the folktale is considered as a metaphoric reflection of the chaotic state of the country in the last years of the Goryeo dynasty and of the deepening social and economic crisis faced by the contemporary masses who were trapped in war and poverty. In addition, the monster's unstoppable appetite for metal things conveys a message of warning about the greed prevalent among leaders and politicians in the Korean society of the time.

As seen in the legend and literary description, Bulgasari is associated with fire. It spits fire, showing off its formidable appearance. It is worth noting that Bulgasari, the seemingly impregnable monster, is ironically killed by fire. 
This paradoxical fate is predicted in the name of the monster. The Korean word "bulgasari" is composed of three Hanja or Chinese characters-"bul" (不: not), "ga” (可: possible), “sal” (殺: kill)—and a noun suffix “i” (伊). The meaning of these morphemes is combined to make a word, "bulgasari” (不可殺伊), which is interpreted to mean "something impossible to kill." Bulgasari, as the name implies, accordingly refers to a monster of immortality. However, there is another way to interpret the meaning of the name. It is possible to replace the first Chinese character "bul" (不: not) with a Hangul or Korean character "bul" (불) with the same pronunciation but different meaning of "fire," which is equivalent to the Chinese character "hwa" (火). In this case, the Korean word "bulgasari" can be transcribed into Chinese characters to make the word "hawgasari" (火可殺伊), which means "something to be killed by fire." According to this interpretation of the name, Bulgasari becomes a monster with mortality, especially vulnerable to fire. As a result, Bulgasari has an ambivalent meaning in its monstrosity, which is that it is impossible to kill and, at the same time, can be killed by fire. In other words, Bulgasari is a grotesque being with incompatible and contradictory identities, immortality and mortality, residing in a single body.

Another folktale explains this mystery entangled in the name of the monster. It is the story of a Buddhist monk in the early years of the Chosun Dynasty. The story goes like this. Yi Seong-Gye, the general who led the overthrow of Goryeo, establishes the Chosun Dynasty and becomes its first king called Taejo. King Taejo replaces the Buddhism of the previous dynasty with Confucianism as the national religious ideology for the new kingdom. King Taejo issues a nationwide decree that all Buddhist monks, the remnants of former regime's religious ideology, should be ferreted out and arrested. Buddhist monks, respected in earlier times, are now outlaws.

During this tumultuous period, a monk manages to hide himself in his brotherin-law's house. He stays alive by eating rice balls brought secretly by his relative. To relieve himself from the boredom of his secluded and monotonous life, the monk kneads the grains of boiled rice into a small doll. Surprisingly, the rice doll comes to life and starts to move and promptly swallows a needle found on the floor. From then on, the doll consumes all the metal things in the house, including nails, spoons, and chopsticks. Every time the doll swallows a metal object, its body increases in size and even its skin gradually turns into metal. The "iron-clad" monster eventually leaves the house and travels every corner of the town sating its appetite. When the size of monster's appetite exceeds its control, the town's governor sends his soldiers to kill it. However, the armed forces are just helpless in front of the monster. They discover the monster eating their weapons and, to make matters worse, the soldiers find that the monster's size is ever-increasing. While at first man-sized, it grows like a snowball and finally becomes as big as a house. Stunned by the monster's 
invulnerability, the soldiers and townspeople begin to call the monster "Bulgasari," meaning "the impossible-to-kill."

The Buddhist monk, taking advantage of this confusion, determines to leave the town seeking refuge in other places. Before departure, he writes something on a slip of paper and hands it over to his brother-in-law, saying that it would be a great help some day. Meanwhile the town's fear of Bulgasari reaches its climax, and the governor promises to offer a big prize and government position to whoever gets rid of the monster. In response, the monk's brother-in-law remembers the paper slip and unfolds it, where he finds a Chinese phrase saying "Bul-Ga-Sal-I-HwaGa-Sal” (不可殺伊火可殺, pronounced as "bulgasari-hwagasal”), meaning that "the impossible-to-kill monster can be killed by fire." By interpreting the phrase, the brother-in-law realizes that only fire can melt the iron-clad monster to death. Accordingly, he kindles a fire to attract Bulgasari and successfully kills the monster. $\mathrm{He}$, in return, gets a chance to enter government service.

\section{BULGASARI IN SILVER SCREEN: FILM BULGASARI (1985)}

The legendary monster Bulgasari also appeared in the silver screen. The North Korean film Bulgasari (1985) deserves attention not only because the film was made in North Korea but also because of the truly dramatic and unusual behindthe-scenes story of its "transnational" birth and aftermath.

The production of the film was planned by the North Korean leader Kim Jong-Il (1941-2011), son of then-ruling Kim Il-Sung (1912-1994) and therefore a powerful figure in North Korea behind his father. Kim Jong-Il, an avid film lover himself, had dreamed of making fantasy propaganda films for his country. He was also a life-long admirer of a legendary South Korean film director, Shin Sang-Ok (19262006). To make his dream come true, Kim kidnapped Shin and his wife, famous actress Choi Eun-Hee (1926- ) in 1978, which became a big issue at that time in South Korean society. Abducted in Hong Kong and taken to Pyongyang in North Korea, Shin embarked on producing the monster film with the full support of Kim Jong-Il. The North Korean blockbuster Bulgasari was completed in December 1985.5

The film was screened for the first time in Japan on July 4, 1998, and the opening was successful in the box office. According to a Japanese local newspaper, the film was screened at the movie house Kinema Omori in Tokyo for eight weeks, and the audience totaled 18,0oo people. This figure reportedly outpaced three times the Japanese monster movie Godzilla's box office at Hollywood in the same 
year (Jung; Lee D.; Noh). There is an interesting back story about the Japanese release of Bulgasari, which reveals why it took such a long time for the film to get premiered after being completed. In March 1986, right after the completion of the film, director Shin and his wife Choi successfully defected from North Korea and eventually returned to South Korea, after eight years. It caused the film to be banned in North Korea for a decade. It was not until July 4, 1998, that the ban was lifted and consequently the film was released for the first time in Japan. It turned out that the name of director Shin, who had closely supervised the filmmaking process, was regrettably removed from the film's credits at the time of the opening in Japan. Instead, a different name, Jeong Geon-Jo, was listed as director, replacing Shin.

Two years later, in May 200o, South Korea's Ministry of Culture and Tourism announced its plan to activate the South-North cultural exchange with the upcoming South-North Summit to be held in June that year as momentum. ${ }^{6}$ Accordingly, the film Bulgasari was released in five movie theaters in Seoul from August 22, and the film is recorded as "the first North Korean film officially released in South Korea" (Na; Noh). However, the film was a total failure in the box office in South Korea. It has reportedly been said that at that time the rating process of the film Bulgasari by the Korea Media Rating Board was delayed, which made it difficult for the film to find places for screening in the mid-summer, the busiest season for movie theaters. To make matters worse, this North Korean film did not have sufficient time to get attention from the audience in South Korea, let alone the chance to promote its 'coming soon' in the South. Whatever the reason, the film turned out to be a total failure despite the favorable factors for box-office success: the rising mood of reconciliation between the two Koreas, the emotional and tearful statement in the poster saying "Has come from the North after a lapse of fifty years!", and the texts emphasizing historical importance saying "North Korean Film No. 1 to be unveiled for the first time in South Korea" in the header of the poster (Figure 3).

In short, the film Bulgasari, born of two Koreas, like an illegitimate child born without knowing the name of its biological father, adopted by another father, and exiled in a foreign country, had lived a checkered life as a member of the Diaspora, and slapped in the face with harsh reality, that is, the two Koreas being so close and yet so far from each other.

The film Bulgasari, based on the legendary story, is set in the last years of the 14th century Goryeo period when a mass of peasants is eking out a scanty livelihood under the tyranny of an exploitative king and corrupt officials, and subsequently the have-nots' anti-sentiment against aristocratic power reaches its peak. The setting of the film not only touches on the existential condition contemporary grassroots people had to survive in, but also on more complex and embarrassing feelings they 


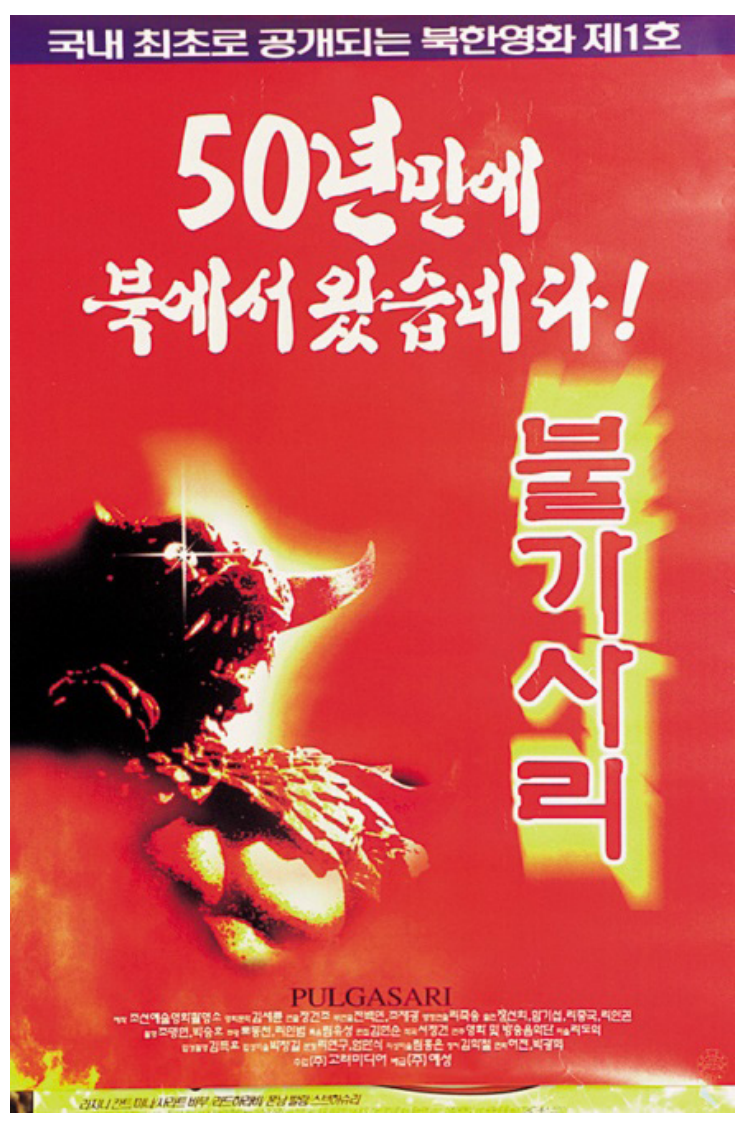

Figure 3. Poster of the film Bulgasari for its release in South Korea (2000)

are forced to have, confronted with the emergence of this bizarre monster comingout-of-nowhere: What is this weird creature? Is it good or bad? Are you with us, or against us? Thus, the film from the beginning links the grassroots people's existential condition and their "recognition" of the "existence" of the monster.

The film begins with a scene in which a young woman Ami is busy bringing water to iron workers. Among the workers is her aged father Taksoe. Making weapons secretly, they are preparing for the peasants' rebellion against the corrupt bureaucrats and the aristocracy. One day a group of government officials visit the place. They dump out the carts of farming utensils and order Taksoe to melt them down into weapons to use against the rebels. The old blacksmith disobeys the order and returns the utensils to the neighboring farmers. He visits the governor the next day and makes a false report that the iron-eating monster Bulgasari has eaten up all the farming tools. Suspicious of what Taksoe says, the governor imprisons him and other workers for attempting to assist the rebels. 
The old man, starved and tortured, is on the verge of death in the prison. He does not eat the food his daughter Ami has brought him. The old man instead molds a small doll from the rice. He names the doll Bulgasari and dies. As the corpse of the old man is being taken out of the prison, Ami discovers the rice doll and takes it home. That night, while sewing, Ami accidently cuts her finger. The blood from her finger drips onto the rice doll in the sewing box. At this moment, the doll comes to life and begins to eat the sewing needles and scissors. The ironeating monster devours the iron latch of the door and leaves the house. It walks around the town, chewing its way through all the metal objects. During the course it grows continuously and eventually towers over trees. The monster frustrates the army's every effort to arrest it and rushes to the governor's residence. It helps free the imprisoned peasants out by eating up the shackles binding theirs hands and destroys the residence and finally the wicked governor himself. The peasants draw strength from the powerful monster and eventually win the battle.

Yet the peasants have to pay for the victory. The peasants have to load up a cart of iron utensils in order to satisfy the unstoppable appetite of the ever-growing monster. Ami realizes that the villagers cannot live comfortably as long as the monster survives and therefore something should be done to stop this vicious cycle of poverty and suffering. She attracts Bulgasari to a remote mountain by ringing a big bell. Arriving at the mountain, Bulgasari discovers the bell and devours it. In the process, the monster also swallows Ami who has been deliberately hiding herself inside the bell. At that moment, the monster turns into a stone and explodes into fragments. From the pile of broken stones a tiny baby Bulgasari comes and toddles around. It turns into a ball of light and immediately disappears into the heart of Ami lying dead.

\section{HUMANITY AND PACIFISM AS MIRRORED BY MONSTROSITY}

As in the legend and literatures mentioned earlier, the monster Bulgasari in the film is given its birth by human beings and more specifically by those who are socially, politically, and economically deprived. Also, it lives among and meets its own destiny with human beings. In the literature, Bulgasari is found in the body of a widow who has "lost" her husband, or created by the hands of a Buddhist monk who has "lost" his own country. Equally in the film, Bulgasari is crafted by a poor peasant, Taksoe, who is "robbed" of his means for living, and given life by a peasant woman, Ami, who has "lost" her father. As in the stories of the widow and the Buddhist monk, the monster in the film is nurtured by "commoners" suffering from poverty and insecurity under the tyranny of exploitative rulers. The originally

lifeless rice doll receives a blood transfusion from Ami and transforms into a living

Kritika Kultura 33/34 (2019/2020): 147-155

(c) Ateneo de Manila University

<http://journals.ateneo.edu/ojs/kk/> 
creature. Then the creature lives on iron goods provided by the peasants. Finally, Bulgasari is killed by and dies with Ami, the mother figure who gave it a life. Thus, Bulgasari the monster shares with the common people its life cycle which ranges from its birth, growth, and its eventual death.

In the film, Bulgasari's presence and subsequent ontological meaning has many layers. Firstly, Bulgasari presents itself in Taksoe's lie to avoid the governor's orders. In Taksoe's makeshift story, Bulgasari is depicted as a mythic and imagined creature. Secondly, Bulgasari presents itself in the body of a rice doll made by Taksoe. Here Bulgasari exists in the form of an imitative copy of the original, the mythical and imaginary monster. After being brought to Ami's home, the rice doll absorbs Ami's blood and comes to life. In this third dimension, Bulgasari is presented as neither imagination nor imitation, but as a real thing of flesh and blood. Likewise, Bulgasari in the film crosses the border between imagination and reality, frequenting different layers of presence and mockingly refusing to be bound to a singular presence and ontological meaning.

It is worth noting that the blood of a human being transforms Bulgasari into a real or living creature. Bulgasari is a monster and at the same time the "Son of Man" having the blood of humanity flowing through its veins. Bulgasari, having a foot in both worlds, and constantly crossing the borderline of the two, finally breaches the supposedly impregnable wall separating the two domains, humanity and monstrosity. Such a "cross-over" ability of Bulgasari blurs the dichotomy between good and evil, by which the monster and the monstrous have been stigmatized as immoral or bestial and easily branded to be a form of an "enduring evil" through history. Thus, Bulgasari in the film has a presence inherently different from that of traditional monsters which have not been freed from the chronic stigma of enduring evil, and subsequently mass-produced to be offered as sacrifice for the aforementioned "monster-making" ritual or political conspiracy of the ruling powers to maintain social norms and the status quo.

As its name implies, Bulgasari is an immortal being and, at the same time, like humans, cannot be freed from death. Therefore, even if the monster is the embodiment of evil, the evil cannot endure forever. As its body tells, Bulgasari is a monster and, at the same time, it is undeniable that human blood is flowing in its veins under its iron skin. To analyze the ideal relationship between bowl and water-the bowl gives the water its shape or form, and the water gives the bowl a function or purpose, "the monstrous skin which contains human blood" represents the whole presence of Bulgasari. Likewise, the monstrous and the human are not completely separate from each other in the body of Bulgasari; rather they are much like having the Yin and Yang relationship. Monstrosity and humanity can be the both sides of human existence. The Jekyll-Hyde story suggests an insight into the 
two sides of human nature, "I" and "my inner Monster" doing battle with each other. Bulgasari is no exception. Whatever the case is, Bulgasari the monster is truly a "human" being.

Bulgasari in the film is also described as a heroic revolutionary who fights for the socially weak and innocent folk against privileged but wicked officials, and seeks to implement social justice by overthrowing the decadent and corrupt social order. This aspect highlights the creature's monstrosity as associated with the people's bottom-up efforts and resistance against the top-down politicization of the ruling class. Likewise, Bulgasari's presence and ontological meaning can be contextualized in such an "uprising" revolutionary spirit of the have-nots. Also likely, the monstrosity and destructive power of the "people-friendly" Bulgasari implies a close connection to the collective sentiment of the common or "proletarian" people in the film. Such a view has provided grounds for the interpretation of this film as a "proletarian" text. A good example is a 1995 review of the film in the proNorth Korean newspaper, Chosun Shinbo, a Japan-based newspaper produced by the Chochongryeon, the pro-North Korean residents' league in Japan. The review says that "Bulgasari fights for the poor peasants against the feudal rulers" (quoted in Lee and Kim).

Dealing with chasm of inequality that sets the oppressive power of the ruling class over the powerlessness of the innocent and ignorant populace, and championing the latter's class struggle, resistance and uprising against the former, the film Bulgasari is definitely a proletarian and pro-revolutionary text. Meanwhile, another overarching theme is found in the film, which is the "pacifism" message as one that goes beyond such hegemonic issues as class antagonism, state power, and proletarian revolution. This is confirmed by Shin Sang-Ok, the director of the film. In a column, he quotes the words of a film critic Kim Young-Hoon who maintains that "North Korean films remain tacky, strange, dreadful, and so-called 'red' movies in the memory of most South Korean people" and points out that it is a biased view of North Korean film. While many Korean critics have interpreted the film Bulgasari as a work of socialist realism, with an intention to inspire class struggle and proletarian revolution, director Shin himself clarifies the film's true message to be pacifism:

Bulgasari draws themes from Korean folklores and can be interpreted in many ways, but most critics seem to see it from the "class-struggle" angle. What I really wanted to deliver was a warning message against the nuclear weapons race, something that could disrupt world peace. (Shin, "Bukhan Yeonghwa Iyaki: Bulgasari"; Shin, Nan Yeonghwa eotta 138; my translation from the original Korean)

Kritika Kultura 33/34 (2019/2020): 149-155 
Since the atomic bombing of Hiroshima and Nagasaki in 1945 and the subsequent end of World War II, humanity has been confronted with a new phase of global conflict called "nuclear holocaust" or a possible annihilation of human civilization by nuclear warfare. In addition to environmental issues, concern over nuclear development and competition has become a matter of reality across the globe, and at every moment of time it threatens the life and livelihood of human beings. As a Korean journalist argues, the Bulgasari text is worth reading and can be read, as Shin presumably intended, among contemporaries in the new century because the universal or transnational theme of pacifism in the film, enwrapped in the allegorical device of an imaginary monster, encounters a real nuclear threat that humanity is currently facing in reality (Jung).

In relation to the pacifism message that the Bulgasari text conveys, not only the monstrosity of Bulgasari but also its humanity that gives life to the monster can be discussed. Bulgasari is itself a hideous monster. But such monstrosity is not inborn. Bulgasari was not a monster from the beginning. As seen in the film, Bulgasari was originally a tiny little rice doll that gains life from a drop of human blood, grows up eating ironware obtained from the human world or provided by human beings, and finally evolves into a dreadful gigantic monster with destructive power. The thing is that humankind is the life-giver to the monster and it is we human beings, whether the ruling class or the ruled, that provide the monster with life and nutrition support in the form of farming tools and weapons. It is none other than human beings that mothered and fostered the monster and its monstrosity, therefore we humans have to help ourselves and take responsibility for the pains, suffering, death and other dismal human conditions caused by the monster.

Turning back to the aforementioned issue of nuclear weapons, and relating it to the war and pacifism discourse embodied by the monstrosity of Bulgasari, we come to a conclusion as follows: it is we humans that created and nurtured the modern monster of nuclear threat, giving it a boost to grow to monstrous proportions to the extent of threatening ourselves. We have none to blame but ourselves, for the blunder is of our own making. Humans are both offenders and victims of the monstrous nuclear threat, and we are not free ourselves from such ambivalent position in the monster-making. The monster may be inside of us. Or, the monster can be none other than our own identity. Like Bulgasari, we humans are the monsters with killing power but we turn out to be vulnerable to the monstrosity of our own creation. If so, is there truly no way out for us to be freed from the fate to be monsters or the anxiety about monsters? To answer this question, a Korean critic proposes as a potential solution for humanity: to embrace the "monster inside me": 
Every society has monsters. They become monsters because they are oppressed to be. [...] Only if we can be honest to each other about the monster inside us, so that we can gain the strength to face up to the inner monstrosity of our own selves, we will be able to be more comfortable together. (Lee M.; my translation from the original Korean)

\section{CONCLUSION}

Scary and cute, violent and docile, fiery to the oppressors but gentle to the oppressed, immortal and mortal, monstrous and humane, evil and good: these are the perceptions of the legendary monster Bulgasari. Such an ambivalent identity has ontological and epistemological distinction from the archetypal imagery and general understanding of monstrosity, represented by Hydra, which have been stigmatized and mythicized as the incarnation of the enduring evil. The destructive power of this people-friendly monster, combined by positive aspects, expresses the bottom-up sentiment of the grassroots who have to overcome hardships with a thousand emotions and tears and hurdle difficult situations that constantly seem insurmountable. Bulgasari becomes a guardian for the weak and the helpless, and an enemy for the overly aggressive. The monster of human flesh and blood, therefore sharing human nature, grows in a human community, and finally ends its life with humans. Thus, the seemingly immortal monster is truly a human being in the sense that it cannot be freed from the fate of death just like human and "mortal" beings. Likewise, Bulgasari resists being rendered into a series of fixed identities.

There is a piece of trivia I forgot to mention. Recently, a scholar provided an insightful analysis of Asian monsters. What is worth noting in the analysis is the problematic generalizing statement of Asian monsters as "gratuitously malevolent toward humanity, fierce, and of course hungry for human flesh" (Gilmore 134). Bulgasari invalidates this generalization. As we have seen, malevolence toward humanity does not characterize Bulgasari. Furthermore, Bulgasari is not hungry for human flesh. It lives on iron goods. Strictly speaking, it is, rather, a vegetarian: according to myth, it eats bamboo sprouts as well as metal things to increase its power to drive out evil spirits.

As an additional piece of trivia, it is interesting to say that the Korean word "bulgasari" also refers to star-shaped echinoderms or starfish in the sea. In the European Christian tradition, starfish are also known as the "sea star" and interestingly connotes "Mary Star of the Sea," an ancient title for the Virgin Mary, symbolizing the grace of God (Cooper 380). The title was used until the 19th century to emphasize Mary's role as a sign of hope and as a guiding star for Christians, and later used as an expression to wish safe passage for those who travel on the sea. Of

Kritika Kultura 33/34 (2019/2020): 151-155

(C) Ateneo de Manila University

<http://journals.ateneo.edu/ojs/kk/> 
course, Westerners would little dream that their "holy" sea star had taken the shape of a monster in the faraway land of Asia. Accidental or not, such a coincidence highlights the Korean mythical monster's unusual ability to cross religious and cultural boundaries, between East and West.

The film Bulgasari is noteworthy as it provides a good example of media appropriation of the mythical story and the creature's nature of monstrosity. Moreover, born of two Koreas, torn in between the two nations, and going through a complicated diasporic life, this film resembles the monster Bulgasari with slippery identities denying to be fixed. In the film, the monstrosity of Bulgasari discourses the issues of humanity and pacifism. Additionally, considered in this critical era of South-North division and nuclear holocaust, these issues can be read not only in Korea-specific but transnational and global contexts. Thus, the film Bulgasari interestingly becomes or turns into a public space where contemporary sociopolitical discourses are observed, discussed, and criticized. 


\section{Notes}

1. This work was supported by Hankuk University of Foreign Studies Research Fund of 2018. This is a revised and extended version of a paper presented at The European Conference on Arts and Humanities, Brighton, UK, 17-20 July 2014.

2. There is disagreement on the number of Cerberus's heads. Although the threeheaded Cerberus is more common in literary descriptions and art, the two-headed Cerberus often appears in Attic paintings, and Hesiod's Theogony, describes Cerberus as the "fifty-headed" dog of Hell (311).

3. Kim Du-Ryang (1696-1763) was a court painter during the reign of King Jeongjo (1752-180o). A member of the Dohwaseo, royal academy of painting, he was good at various genres of painting including muninhwa (painting in the literal artistic style), sansuhwa (landscape painting), and inmulhwa (portrait painting). His drawing entitled "Bulgasari" was completed in the late 18th century and survives today.

4. The Red Turban Bandit, a group of Chinese thieves, originated in the north of the Yellow River in China, between 1351 and 1368, by the followers of the White Lotus Society to resist the Mongols' Yuan Kingdom who ruled China at that time. The bandit members wore red turbans and carried red banners to distinguish themselves. Toward the end of the Yuan Kingdom, the Red Turbans frequently invaded the territory of Goryeo.

5. The number of extras and other actors employed in this film alone amounted to 13,0oo. Teruyoshi Nakano and the staff from Japan's Toho Studio, the creators of the Hollywood Godzilla (1985), participated in creating the film's special effects (Back Row Banter 2010). Nakano is a notable Japanese special effects director especially famous for his work for the Godzilla film series. Kenpachiro Satsuma, a Japanese stunt actor known for playing Godzilla in the film series (1984-1995), impersonated Bulgasari.

6. The Kim Dae-Joog administration of South Korea adopted the "Sunshine Policy" as its North Korea policy in 1998. Adopting a neo-functionalist view, the South Korean government encouraged private business ventures in North Korea and expanded the fertilizer and food aid to the North on a humanitarian level, with the aim of actualizing the North Korean project at the government level. The historic inter-Korean Summit in June 2000 signalled the move toward peaceful coexistence between the Koreas. After the June 15 Joint Declaration, follow-up efforts continued, including ministerial talks, the Red Cross talks, and the establishment of the Economic Cooperation Promotion Committee (Chon 3). As a newspaper columnist recalls, "When the leaders of the two Koreas, Kim DaeJoong and Kim Jong-Il, embraced at Sunan Airport in North Korea, expectations that this first-ever Summit would lead to reconciliation ran high in South Korea and around the world" (Breen 2010). The 2010 Summit was the dramatic visualization of the Kim administration's North Korean "sunshine" policy.

Kritika Kultura 33/34 (2019/2020): 153-155

(C) Ateneo de Manila University

<http://journals.ateneo.edu/ojs/kk/> 


\section{Works Cited}

Bloomfield, Maurice. Cerberus, the Dog of Hades: The History of an Idea. Open Court, 1905.

Breen, Michael. "Inter-Korean summit and years of Sunshine policy." The Korea Times. 20 June 2010. www.koreatimes.co.kr/www/news/nation/2010/o6/116_67970.html. Accessed 9 Feb. 2017.

Cho, Jae-Hyun. "Gojeonseosa e Natananeun 'Bulgasari' Yeongu” (The Study of Bulgasari on the Classic Narrations). Eomun Yeongu (Language and Literature Studies), vol. 38, no. 1, 2010, pp. 155-177.

Chon, Hyun-joon. "The Inter-Korean Summit: Evaluation and Tasks Ahead." East Asian Review, vol. 14, no. 2, 2002, pp. 3-16.

Chung, Ha-Seob. Soe reul Meok neun Bulgasari (Bulgasary the Metal Eater). Gilbeot Eorini, 1998.

Cooper, Jean C. An Illustrated Encyclopaedia of Traditional Symbols. Translated by Yoon-Ki Lee. Khachi, 1994.

Gilmore, David D. Monster: Evil Beings, Mythical Beasts, and All Manner of Imaginary Terrors. U of Pennsylvania P, 2003.

Hesiod. Theogony and Works and Days. Translated by Catherine M. Schlegel and Henry Weinsfield. U of Michigan P, 2006.

Heo, Ggyun. Jeontong Misul ui Sojae wa Sangjing (Material and Symbols of the Traditional Arts). Kyobo, 1991.

Homer. The Iliad. Translated by Robert Fagles. Penguin, 1998.

Hyun, Young-Sun. Songdo Malnyeon ui Bulgasari-jeon (The Tale of Bulgasari at the Last Years of Songdo). Kwangdong Seokwan, 1921.

Jung, Deok-hyun. "Gongpo ga mandeuleonaen Bulgasari: Bukhaek gwa Yanggeukhwa" (Bulgasari Created by Fear: North Korea's Nuclear Effort and Polarization). Ohmy News. 25 Oct. 2006. http://www.ohmynews.com/NWS_Web/view/at_pg.aspx?CNTN_ $\mathrm{CD}=$ Aoooo368898. Accessed 9 Feb. 2017.

Kim, Young-Hoon. "Bukhan Yeonghwa Eoteokke Bol Geoshinga" (How Should We Look upon the North Korean Films). Tal Bundan Shidae reul Yeolmyeo (Opening a PostDivision Age). Edited by Hye-Jeong Chohan and Woo-Young Lee. Samin, 2000.

Lee, Dong-jin. "Minjung Wihae Sauneun Goesu Bulgasari” (Monster Bulgasari Fighting for the People). Chosun Ilbo (Chosun Daily News). July 18, 200o. http://nk.chosun.com/ news/articleView.html?idxno=3302. Accessed 9 Feb. 2017

Lee, Myeong-Ja. "Goemul Bulgasari, Buran ui Jaehyeon" (Monster Bulgasari, the Representation of Anxiety). Minjok 21. 1 Oct. 2006. http://www.minjog21.com/news/ articleView.html?idxno=2295. Accessed 1 Aug. 2016.

Lee, Sang-Soo, and Eun-young Kim. "Bukhan eul Jeulgyeoboryeom!" (Enjoy the North Korea!). Hankyeorae 21. 22 June 200o. http://www.hani.co.kr/h21/data/ Looo612/1pbc6c04.html. Accessed 1 Aug. 2016.

Linebaugh, Peter, and Marcus Rediker. The Many-Headed Hydra: The Hidden History of the Revolutionary Atlantic. Beacon, 2001. 
Na, Do-won. "Movie: Bulgasari." Gaseum Network. 8 Dec. 2004. http://news.khan.co.kr/ kh_news/khan_art_view.html?art_id=200412021528051. Accessed 9 Feb. 2017.

Noh, Soon-dong. "Bukhan Yeonghwa Gaebong 1ho, Bulgasari" (First North Korean Movie Opening in South, Bulgasari). Sisa Journal. 27 July 200o. http://www.sisajournal.com/ news/articleView.html?idxno=91684. Accessed 5 Feb. 2017.

Shin, Sang-Ok. Nan Yeonghwa eotta (I Was the Movie). Random House Korea, 2007.

--. "Bukhan Yeonghwa Iyaki: Bulgasari" (Tales on North Korean Films: Bulgasari). NK Chosun. 15 Oct. 20oo. http://nk.chosun.com/news/articleView.html?idxno=3710. Accessed 9 Feb. 2017.

“The Dear Leader, The Director and the Director's Wife." Back Row Banter. 27 May 2010. https://backrowbanter.wordpress.com/2010/05/27/shin/. Accessed 9 Aug. 2016.

Yoon, Yeol-Su. Minhwa Iyagi (The Story of Folk Painting). Design House, 1995.

-. Shinhwa Sok Sangsangdongmul Yeoljeon (Imaginary Animals in Mythology). Korea Cultural Heritage Foundation, 2010. 